\title{
Positive results for patients with COVID-19 discharged form hospital in Chongqing, China
}

\author{
Wang Deng ${ }^{1,2+}$, Tian-wen Guang ${ }^{3+}$, Mei Yang ${ }^{4}$, Jian-rong Li ${ }^{5}$, De-peng Jiang ${ }^{1,2}$, Chang-yi $\mathrm{Li}^{1,2}$ and \\ Dao-xin Wang ${ }^{1,2^{*}}$
}

\begin{abstract}
Background: Since December 2019, over 80,000 patients with coronavirus disease 2019 (COVID-19) have been confirmed in China. With the increasing number of recovered patients, more attention should be paid to the follow-up of these patients.

Methods: In the study, 576 patients with COVID-19 discharged from hospital in Chongqing, China from January 24, 2020, to March 10, 2020 were evaluated by viral nucleic acid tests for severe acute respiratory syndrome coronavirus 2(SARS-CoV-2) to determine if they could be released from quarantine. Among the 576 patients, 61 patients (10.6\%) had positive RT-PCR test results of SARS-CoV-2. We aimed to analyze the demographics, clinical characteristics and treatment of 61 patients.

Results: These positive patients were characterized by older age, chronic medical illness and mild conditions. 38 (62.3\%) patients who were asymptomatic without abnormalities on chest radiographs were found in the positive with COVID-19. Also, they showed positive results of stool or sputum specimens with negative results of nasal and pharyngeal swab specimens. The median duration of positive result of SARS-CoV-2 was varied from 3 days to 35 days in the patients discharged from hospital with no family member infection.

Conclusions: Multi-site screening of SARS-CoV-2 including nasal and pharyngeal swabs, stool and sputum specimens could be considered to improve the diagnosis, treatment and infection control in patients with COVID-19. Our findings provide the important information and clinical evidence for the improved management of patients recovered from COVID-19.
\end{abstract}

Keywords: Coronavirus disease 2019, Hospital discharge, SARS-CoV-2

\section{Background}

Since December 2019, an unknown pneumonia broke out in Wuhan, Hubei Province, China, which has rapidly spread from China to at least 200 countries abroad. A

\footnotetext{
* Correspondence: 303528@hospital.cqmu.edu.cn

${ }^{+}$Wang Deng and Tian-wen Guang contributed equally to this work. 'Department of Respiratory and Critical Care Medicine, Second Affiliated Hospital of Chongqing Medical University, 76 Linjiang Road, Yuzhong District, Chongqing 400010, China

${ }^{2}$ Chongqing Medical Research Center for Respiratory and Critical Care Medicine, Chongqing 400010, China

Full list of author information is available at the end of the article
}

novel coronavirus disease 2019 (COVID-19) was identified with the similar clinical manifestations to severe acute respiratory syndrome (SARS) and Middle East respiratory syndrome (MERS) [1]. COVID-19 was issued a global outbreak and pandemic by World Health Organization [2] with over 3,000,000 confirmed cases by April 29, 2020.So far, more than 80,000 patients with COVID-19 has been confirmed in China. Elderly patients with co-morbidities were prone to develop the high risk for severe and critically ill situation and require intensive care medical interventions $[3,4]$. With the

C C The Author(s). 2020 Open Access This article is licensed under a Creative Commons Attribution 4.0 International License, which permits use, sharing, adaptation, distribution and reproduction in any medium or format, as long as you give appropriate credit to the original author(s) and the source, provide a link to the Creative Commons licence, and indicate if changes were made. The images or other third party material in this article are included in the article's Creative Commons licence, unless indicated otherwise in a credit line to the material. If material is not included in the article's Creative Commons licence and your intended use is not permitted by statutory regulation or exceeds the permitted use, you will need to obtain permission directly from the copyright holder. To view a copy of this licence, visit http://creativecommons.org/licenses/by/4.0/ The Creative Commons Public Domain Dedication waiver (http://creativecommons.org/publicdomain/zero/1.0/) applies to the data made available in this article, unless otherwise stated in a credit line to the data. 
increasing number of recovered patients discharged from hospital by regular follow-up and medical observation, some medical professionals were found to be positive for COVID-19 after hospital discharge [5], and more attention should be paid to the follow-up of non- medical patients.

Severe acute respiratory syndrome coronavirus 2(SARS-CoV-2) can be detected in the specimens of upper respiratory tract, stool and lower respiratory tract [6]. Currently, a small number of positive results of SARS-CoV-2 in some recovered patients have been reported $[1,7,8]$, but the management of these positive patients still remains an unsolved problem. In addition, there is a lack of clinical characteristics, the potential impact and significance of positive patients recovered from COVID-19, which makes it difficult to provide clinical evidence and experience for the management of patients with COVID-19 in the recovery period.

The objectives of this study were to investigate the clinical characteristics of patients discharged form hospital with positive results of SARS-CoV-2. In the study, 576 patients with COVID-19 discharged from hospital were retrospectively analyzed in Chongqing, China. Among them, 61 patients had positive results of SARSCoV-2 by real-time reverse transcriptase polymerase chain reaction (RT-PCR) test, which provided the important information and clinical evidence for the improved management of patients recovered from COVID19.

\section{Methods}

Five hundred seventy-six patients with COVID-19 discharged from Chongqing Public Health Medical Center, Yongchuan Affiliated Hospital of Chongqing Medical University, and Wanzhou General Hospital, Chongqing, China, from January 24, 2020, to March 10, 2020 were evaluated by RT-PCR assay for SARS-CoV-2 according to the manufacturer's protocol (Jiangsu Perfectus Biotechnology Co., Ltd., patch No. JC10223-1 N) to determine if they could be released from quarantine at home. Recovered patients discharged from hospital or discontinuation of quarantine should meet the following criteria [9]: (1) normal temperature for more than 3 days, (2) significant improvement of respiratory symptoms, (3) significant absorbtion of acute exudative lesions on chest radiograph and (4) two consecutively negative results by RT-PCR assay of nasal and pharyngeal swabs with at least 1 day interval.

We extracted the clinical symptoms information, laboratory findings and radiologic abnormality form electronic medical records. Patients were recommended quarantine at home after hospital discharge and returned to hospital for viral nucleic acid detection by RT-PCR. Nasal and pharyngeal swab specimens were collected as previously described [10]. Stool and sputum specimens were also collected for viral nucleic acid detection by RT-PCR. Two consecutively tests by RT-PCR of nasal and pharyngeal swab specimens, stool and sputum specimens were performed with at least 1 day interval combined with chest radiograph during the quarantine period.

Continuous variables were presented as mean (SD) or median (IQR) and categorical variables as count (\%).SPSS (version 13.0) was used for all analysis.

The study was approved by the Ethics Committee of the Second Affiliated Hospital of Chongqing Medical University and the need for informed consent was waived. The patients have not been reported in any other submission by anyone else.

\section{Results}

Among the patients discharged from hospital, 61 (10.6\%) patients had positive results of SARS-CoV-2 by RT-PCR tests. None of the patients were medical professionals. Demographics, clinical characteristics and treatment of 61 patients were shown in Table 1 . The median age of 61 patients was 54.79 years, including 36(59\%) female patients and $25(41 \%)$ male patients. 24 (39.3\%) patients had chronic diseases, including chronic obstructive pulmonary disease, hypertension, diabetes, digestive system disease, cerebrovascular disease, chronic kidney disease and chronic hepatitis. 38 (62.3\%) patients were asymptomatic. The most common symptoms were fever (24.6\%), cough $(18 \%)$, sputum production $(14.8 \%)$, and sore throat $(13.1 \%)$, while the less common symptoms were headache (8.2\%), shortness of breath (4.9\%), fatigue (4.9\%) and diarrhea (4.9\%). On admission, leucocytes were above the normal range in $8(13.1 \%)$ patients and below the normal range in $11(18 \%)$ patients.14 (22.9\%) patients had neutrophils above the normal range. Lymphocytes and platelets were below the normal range in $17(27.9 \%)$ patients and 4(6.6\%) patients respectively. Nine patients had different degrees of liver function abnormality, with the increase in alanine aminotransferase or aspartate aminotransferase (Table 1). Most patients (95.1\%) had hypoproteinemia. Fourteen patients had different degrees of renal function damage, with the elevation of blood urea nitrogen or serum creatinine. Chest computed tomography (CT) scan of symptomatic patients showed local patchy shadowing (14.8\%), groundglass opacity (4.9\%), bilateral patchy shadowing (13.1\%) and interstitial abnormalities (4.9\%). Normal CT imaging was showed in asymptomatic patients. The severity of disease was mild status in 38(62.3\%) patients.

Sixty-one patients were received treatment for 18 days (IQR 14.0-22.5) and had two consecutively negative results of nasal and pharyngeal swab specimens by RT-PCR before discharge. They were required to continue the 
Table 1 Demographics, clinical characteristics and treatment of patients recovered from COVID-19 with positive results of SARSCoV-2

\begin{tabular}{l}
\hline Age, years \\
$\leq 29$ \\
$30-39$ \\
$40-49$ \\
$50-59$ \\
$60-69$ \\
$70-79$ \\
Sex \\
Female \\
Male \\
Chronic medical illness \\
Chronic obstructive pulmonary disease \\
Hypertension \\
Diabetes \\
Digestive system disease \\
Cerebrovascular disease \\
Chronic kidney disease \\
Chronic hepatitis
\end{tabular}

Symptoms after discharge from hospital

Fever
Sore throat
Cough
Shortness of breath
Sputum production
Headache
Fatigue
Diarrhoea
Asymptom
Positive results
Nasal and pharyngeal swab
Stool
Sputum

\section{Disease severity status}

Mild

General

Severe

Critical

\section{Laboratory findings}

Leucocyte count $\left(\times 10^{9}\right.$ per Li normal range $3.5-9.5$ )

$$
\begin{aligned}
& >9.5 \\
& <3.5
\end{aligned}
$$

Neutrophil count $\left(\times 10^{9}\right.$ per Li normal range $1.8-6.3)$

$$
>6.3
$$

Lymphocyte count $\left(\times 10^{9}\right.$ per L; normal range 1.1-3.2)

$<0.8$

Platelets count $\left(\times 10^{9}\right.$ per $\mathrm{L}$; normal
Patients $(n=61)$

54.79 (12.89)

$3(4.9 \%)$

$7(11.5 \%)$

$12(19.7 \%)$

$18(29.5 \%)$

$15(24.6 \%)$

$6(9.8 \%)$

$36(59 \%)$

$25(41 \%)$

$24(39.3 \%)$

$8(13.1 \%)$

$5(8.2 \%)$

$5(8.2 \%)$

$2(3.3 \%)$

$1(1.6 \%)$

$1(1.6 \%)$

$2(3.3 \%)$

$15(24.6 \%)$

$8(13.1 \%)$

$11(18 \%)$

$3(4.9 \%)$

$9(14.8 \%)$

$5(8.2 \%)$

$3(4.9 \%)$

$3(4.9 \%)$

$38(62.3 \%)$

$36(59 \%)$

$17(27.9 \%)$

$8(13.1 \%)$

38 (62.3\%)

$20(32.8 \%)$

$3(4.9 \%)$

0

$6.9(4.5-8.5)$

$8(13.1 \%)$

$11(18 \%)$

$4.9(3.4-5.9)$

$14(22.9 \%)$

$1.5(0.8-1.9)$

$17(27.9 \%)$

$155(128-175)$
Table 1 Demographics, clinical characteristics and treatment of

\begin{tabular}{|c|c|}
\hline & Patients $(n=61)$ \\
\hline \multicolumn{2}{|l|}{ range $100-300)$} \\
\hline$<100$ & $4(6.6 \%)$ \\
\hline \multicolumn{2}{|l|}{ Procalcitonin, ng/mL (normal range $<0.05$ ) } \\
\hline$\geq 0.05, \mathrm{n}(\%)$ & $6(9.8 \%)$ \\
\hline C-reactive protein ( $\mathrm{mg} / \mathrm{L}$; normal range $0-5$ ) & $3.2(1.7-28.6)$ \\
\hline$\geq 5.0$ & $19(31.1 \%)$ \\
\hline D-dimer (mg/L; normal range 0-500) & $164(65-327)$ \\
\hline$>500$ & $7(11.5 \%)$ \\
\hline Albumin ( $\mathrm{g} / \mathrm{L}$; normal range $40-55$ ) & $33.7(28.4-37.6)$ \\
\hline$<40$ & $58(95.1 \%)$ \\
\hline $\begin{array}{l}\text { Alanine aminotransferase }(\mathrm{U} / \mathrm{L} \text {; } \\
\text { normal range } 9-50)\end{array}$ & $27(19-36)$ \\
\hline$>50$ & $5(8.2 \%)$ \\
\hline $\begin{array}{l}\text { Aspartate aminotransferase (U/L; } \\
\text { normal range15-40) }\end{array}$ & $24(15-33)$ \\
\hline$>40$ & $4(6.6 \%)$ \\
\hline $\begin{array}{l}\text { Blood urea nitrogen }(\mathrm{mmol} / \mathrm{L} ; \\
\text { normal range3.6-9.5) }\end{array}$ & $6.1(4.7-7.3)$ \\
\hline$>9.5$ & $5(8.2 \%)$ \\
\hline $\begin{array}{l}\text { Serum creatinine }(\mu \mathrm{mol} / \mathrm{L} ; \text { normal } \\
\text { range } 57-111)\end{array}$ & $80(67-95)$ \\
\hline$>111$ & $9(14.8 \%)$ \\
\hline $\begin{array}{l}\text { Lactate dehydrogenase }(\mathrm{U} / \mathrm{L} ; \text { normal } \\
\text { range } 120-250)\end{array}$ & $172(150-262)$ \\
\hline$>250$ & $14(22.9 \%)$ \\
\hline \multicolumn{2}{|l|}{ Radiologic findings } \\
\hline Abnormalities on chest radiograph & $23(37.7 \%)$ \\
\hline Ground-glass opacity & $3(4.9 \%)$ \\
\hline Local patchy shadowing & $9(14.8 \%)$ \\
\hline Bilateral patchy shadowing & $8(13.1 \%)$ \\
\hline Interstitial abnormalities & $3(4.9 \%)$ \\
\hline Normalities on chest radiograph & $38(62.3 \%)$ \\
\hline Length of stay in hospital, days & $18.0(14.0-22.5)$ \\
\hline $\begin{array}{l}\text { Length of positive result for COVID-19 } \\
\text { after hospital discharge, days }\end{array}$ & $10(7-13)$ \\
\hline$<14$ & $47(77 \%)$ \\
\hline $14-28$ & $9(14.8 \%)$ \\
\hline$>28$ & $5(8.2 \%)$ \\
\hline \multicolumn{2}{|l|}{ Treatment } \\
\hline Oxygen therapy & $21(34.4 \%)$ \\
\hline Non-invasive mechanical ventilation & $2(3.3 \%)$ \\
\hline Antiviral treatment & $23(37.7 \%)$ \\
\hline Antibiotic treatment & $20(32.8 \%)$ \\
\hline Glucocorticoids & $2(3.3 \%)$ \\
\hline Convalescent plasma therapy & $3(4.9 \%)$ \\
\hline \multicolumn{2}{|l|}{ Clinical outcomes at data cutoff } \\
\hline Hospitalization & $22(36.1 \%)$ \\
\hline Hospital Discharge & $1(1.6 \%)$ \\
\hline Centralized isolation for medical observation & $38(62.3 \%)$ \\
\hline
\end{tabular}
patients recovered from COVID-19 with positive results of SARSCov-2 (Continued)

Data are $\mathrm{n}(\%)$, mean (SD) and median (IQR).OVID-19: coronavirus disease 2019 SARS-CoV-2: severe acute respiratory syndrome coronavirus 2 
quarantine at home for at least 14 days. During the isolation period, 36 (59\%) patients had positive results of SARS-CoV-2 by nasal and pharyngeal swabs;17(27.9\%) patients had positive results of SARS-CoV-2 by stool; 8 (13.1\%) patients had positive results of SARS-CoV-2 by sputum. From the day of hospital discharge, 47(77\%) patients had positive results of SARS-CoV-2 for less than 14 days, whereas $14(23 \%)$ patients had positive results for more than 14 days (Table 1 ). The median duration of positive RT-PCR test results of SARS-CoV-2 was 10 days (IQR 7-13) in 61 patients discharged from hospital with the shortest length of 3 days and longest length of 35 days. They had no contact with any person presenting respiratory symptoms. No family member infection was found.

23(37.7\%) patients were administered antiviral therapy (lopinavir/ritonavir) and $20(32.8 \%)$ patients received empirical antibiotic treatment. 2 (3.3\%) patients were given systematic corticosteroids. 3 (4.9\%) patients were given convalescent plasma therapy. By March 10, 2020, $22(36.1 \%)$ patients were remained in hospital. 1 (1.6\%) patients was discharged and $38(62.3 \%)$ patients with no symptoms were maintained isolation for medical observation before negative results of viral nucleic acid detection.

\section{Discussion}

Currently, the diagnosis of SARS-CoV-2 is dependent on viral nucleic acid detection. Sixty-one patients with COVID-19 had positive results by RT-PCR that fulfilled the criteria for hospital discharge during or more than the 14-day quarantine period. The underlying mechanisms of positive results of SARS-CoV-2 in recovered patients with COVID-19 remain unclear. The major factors including the different sampling tissues [11], false negative of RT-PCR test [12], immunological status [13], viral load and intermittent shedding [14], and viral distribution [15] are currently considered for the possible reasons of re-detectable positive. In the study, though both ORF1b gene and N gene of SARS-CoV-2 were detected using commercial kit, false-negative of test kit may partially account for the reason as previously reported [16]. According to our results, the rate of falsenegative in virus detection was lower than a recent study reported by Xiao et al [17]. We found most recovered patients had hypoproteinemia, suggesting nutritional status probably involved for the positive results.

In the study, most patients (88.9\%) with sputum production had positive results of SARS-CoV-2 after discharge. In addition, the median duration of positive result of SARS-CoV-2 was varied from 3 days to 35 days after hospital discharge, suggesting the intermittent shedding of virus might occur in recovered patients. Fourteen patients had positive results of stool specimens for more than 14 days with negative results of nasal and pharyngeal swabs, suggesting viral shedding from the digestive system lasting longer than that from the respiratory tract. Therefore, stool or sputum specimen-testing might be benefit for the detection of SARS-CoV-2 in determining the diagnosis, treatment and termination of quarantine $[18,19]$. Positive results of SARS-CoV-2 determined by stool and sputum also indicated that viral distribution in different sampling tissues and multiple shedding routes [20,21]. Positive results occurred in most recovered patients with COVID-19 might not be caused by virus recurrence or second virus infection. Sampling tissues of multiple sites could be considered for recovered patients with COVID-19. In this study, patients with two consecutively negative results of nasal and pharyngeal swabs were shown positive results of stool or sputum specimens using RT-PCR test after discharge, indicating the necessity of stool and sputum specimens by RT-PCR adding to the criteria for discharge or discontinuation of quarantine.

The positive rate of specimen detection is limited by the level of viral nucleic acid [11]. The detection of virus RNA was dependent on viral load, suggesting the potential SARS-CoV-2 replication in different sampling tissues [22]. Viral nucleic acid was detected by ORF1b gene and $\mathrm{N}$ gene of SARS-CoV-2 in the study. It was difficult for RT-PCR to distinguish the viral activity. Despite the compliance with discharge criteria, viral RNA remained positive in nasal and pharyngeal swabs, stool and sputum specimens in the recovered patients with COVID19. Viral residual and delay in clearance of viral RNA might be considered as the potential factors [7]. Further studies should address isolation of SARS-CoV-2 in tissue specimens of recovered patients to identify the viral activity. Also, the IgM-IgG combined assay in blood samples could be considered for the potentially rapid screening of SARS-CoV-2 infection in patients [23].

For a small proportion of patients who had positive results of SARS-CoV-2 for more than 14 days, virus carrier status probably existed. Appropriate prolongation of isolation period should be also further proposed. The transmissibility of COVID-19 is mainly dependent on the high level of SARS-CoV-2 shedding in the upper respiratory tract, even among presymptomatic patients [24]. More than half of residents with positive results of SARS-CoV-2 were asymptomatic in a skilled nursing facility reported by Arons et al. [25] The viral load of asymptomatic patients with positive results of SARSCoV-2 was similar to that in symptomatic patients, indicating the potential transmission [26]. Therefore, asymptomatic infection may play an important role in the spread of SARS-CoV-2.In our study, the screening protocol of asymptomatic patients during quarantine period for viral nucleic acid detection was necessary for management and control transmission. Surprisingly, non-infected family members were reported during 
home quarantine in the study. The management of asymptomatic patients with COVID-19 requires further investigation. Patients with symptoms, abnormalities on chest radiograph and abnormal laboratory results were received antiviral treatment in time. Convalescent plasma therapy was performed in severe patients.

The study has a limitation of small sample of patients with COVID-19 discharged form hospital. Also, the lack of serum-specific antibody levels testing in the recovered patients with COVID-19 was due to the shortage of testing load and medical resource and clinical workload in the frontline during the outbreak. A larger cohort study is necessary to investigate the prognosis and transmission risk of recovered patients with COVID-19.

\section{Conclusions}

The study revealed the clinical features of recovered patients with the recurrence of positive results of SARSCoV-2.Multi-site screening including nasal and pharyngeal swabs, stool and sputum specimens could be considered to improve the diagnosis, treatment and infection control in patients with COVID-19. These findings provide the important information and clinical evidence for the management of recovered patients with COVID-19. Criteria for hospital discharge or discontinuation of quarantine would be updated with the progress of clinical evidence and experience accumulation.

\section{Abbreviations}

COVID-19: Coronavirus disease 2019; CT: Computed tomography; MERS: Middle East respiratory syndrome; RT-PCR: Real-time reverse transcriptase-polymerase chain reaction; SARS-CoV-2: Severe acute respiratory syndrome coronavirus 2; SARS: Severe acute respiratory syndrome

\section{Acknowledgements}

We thank Dr. Judy zhao from Crystal Run Healthcare, New York, USA for revising and reading the manuscript.

\section{Authors' contributions}

WD and TWG interpreted the data and drafted the manuscript. MY, JRL, DPJ and CYL collected the data and performed the literature search. DXW proposed the idea of the manuscript. All authors have read and approved the manuscript.

\section{Funding}

This work is supported by grant from the National Natural Science Foundation of China (81600058), grants from the Clinical Medical Study Program of.

Chongqing Medical University, China (XGFY-2019-040) and Key projects of Chongqing Medical University, China (XGFY-2019-06). All authors have read and approved the manuscript. The funders had no role in study design, data collection and analysis, decision to publish, or preparation of the manuscript.

\section{Availability of data and materials}

All data analyzed during this study are included in this published article. The raw datasets used for the analysis are available from the corresponding author on reasonable request.

\section{Ethics approval and consent to participate}

The study was approved by the Ethics Committee of the Second Affiliated Hospital of Chongqing Medical University and the need for informed consent was waived. The data used in this study was anonymised before its use.
Consent for publication

Not applicable.

\section{Competing interests}

The authors declare that they have no conflicts of interests.

\section{Author details}

'Department of Respiratory and Critical Care Medicine, Second Affiliated Hospital of Chongqing Medical University, 76 Linjiang Road, Yuzhong District, Chongqing 400010, China. ${ }^{2}$ Chongqing Medical Research Center for Respiratory and Critical Care Medicine, Chongqing 400010, China. ${ }^{3}$ Department of Infectious Disease, Yongchuan Affiliated Hospital of Chongqing Medical University, 439 Xuanhua Road, Yongchuan District, Chongqing 402160, China. ${ }^{4}$ Department of Respiratory Medicine, Chongqing Public Health Medical Center, 109 Baoyu Road, Shapingba District, Chongqing 400036, China. ${ }^{5}$ Department of Respiratory Medicine, Wanzhou General Hospital, 27 Guoben Road, Wanzhou District, Chongqing 404100, China.

Received: 16 March 2020 Accepted: 11 June 2020

Published online: 19 June 2020

\section{References}

1. Zhu N, Zhang D, Wang W, Li X, Yang B, Song J, et al. A novel coronavirus from patients with pneumonia in China, 2019. N Engl J Med. 2020;382(8): 727-33.

2. WHO characterizes COVID-19 as a pandemic. https://www.who.int/ emergencies/diseases/novel-coronavirus-2019/events-as-they-happen. Accessed 14 Mar 2020.

3. Du RH, Liang LR, Yang CQ, Wang W, Cao TZ, Li M, et al. Predictors of mortality for patients with COVID-19 pneumonia caused by SARS-CoV-2: a prospective cohort study. Eur Respir J. 2020;55(5):2000524.

4. Zhou F, Yu T, Du R, Fan G, Liu Y, Liu Z, et al. Clinical course and risk factors for mortality of adult inpatients with COVID-19 in Wuhan, China: a retrospective cohort study. Lancet. 2020;395(10229):1054-62.

5. Lan L, Xu D, Ye G, Xia C, Wang S, Li Y, et al. Positive RT-PCR test results in patients recovered from COVID-19. JAMA. 2020;323(15):1502-3.

6. Hong KH, Lee SW, Kim TS, Huh HJ, Lee J, Kim SY, et al. Guidelines for laboratory diagnosis of coronavirus disease 2019 (COVID-19) in Korea. Ann Lab Med. 2020;40(5):351-60.

7. Ling $Y, X u S B, L i n ~ Y X$, Tian D, Zhu ZQ, Dai FH, et al. Persistence and clearance of viral RNA in 2019 novel coronavirus disease rehabilitation patients. Chin Med J. 2020;133(9):1039-43.

8. Qu YM, Kang EM, Cong HY. Positive result of SARS-Co-2 in sputum from a cured patient with COVID-19. Travel Med Infect Dis. 2020;34:101619.

9. China National Health Commission. Guidelines for the diagnosis and treatment of COVID-19 pneumonia (trial version 6). 2020. In Chinese. http:// www.nhc.gov.cn/yzygj/s7653p/202002/8334a8326dd94d329df351 d7da8aefc2.shtml. Accessed 19 Feb 2020.

10. Huang C, Wang Y, Li X, Ren L, Zhao J, Hu Y, et al. Clinical features of patients infected with 2019 novel coronavirus in Wuhan, China. Lancet. 2020;395(10223):497-506.

11. Zhang B, Liu S, Dong Y, et al. Positive rectal swabs in young patients recovered from coronavirus disease 2019 (COVID-19). J Infect. 2020;S01634453(20)30233-4. https://doi.org/10.1016/j.jinf.2020.04.023.

12. Li D, Wang D, Dong J, Wang $\mathrm{N}$, Huang $\mathrm{H}$, Xu H, et al. False-negative results of real-time reverse-transcriptase polymerase chain reaction for severe acute respiratory syndrome coronavirus 2: role of deep-learning-based CT diagnosis and insights from two cases. Korean J Radiol. 2020;21(4):505-8.

13. Chen G, Wu D, Guo W, Cao Y, Huang D, Wang H, et al. Clinical and immunological features of severe and moderate coronavirus disease 2019. J Clin Invest. 2020;130(5):2620-9.

14. Yu F, Yan L, Wang N, Yang S, Wang L, Tang Y, et al. Quantitative detection and viral load analysis of SARS-CoV-2 in infected patients. Clin Infect Dis. 2020. https://doi.org/10.1093/cid/ciaa345.

15. Xia J, Tong J, Liu M, Shen Y, Guo D. Evaluation of coronavirus in tears and conjunctival secretions of patients with SARS-CoV-2 infection. J Med Virol. 2020. https://doi.org/10.1002/jmv.25725.

16. Li Y, Yao L, Li J, Chen L, Song Y, Cai Z, et al. Stability issues of RT-PCR testing of SARS-CoV-2 for hospitalized patients clinically diagnosed with COVID-19. J Med Virol. 2020. https://doi.org/10.1002/jmv.25725. 
17. Xiao AT, Tong YX, Zhang S. False-negative of RT-PCR and prolonged nucleic acid conversion in COVID-19: rather than recurrence. J Med Virol. 2020. https://doi.org/10.1002/jmv.25855

18. Lin C, Xiang J, Yan M, Li H, Huang S, Shen C. Comparison of throat swabs and sputum specimens for viral nucleic acid detection in 52 cases of novel coronavirus (SARS-Cov-2)-infected pneumonia (COVID-19). Clin Chem Lab Med. 2020. https://doi.org/10.1515/cclm-2020-0187.

19. Zhang W, Du RH, Li B, Zheng XS, Yang XL, Hu B, et al. Molecular and serological investigation of 2019-nCoV infected patients: implication of multiple shedding routes. Emerg Microbes Infect. 2020;9(1):386-9.

20. Holshue ML, DeBolt C, Lindquist S, Lofy KH, Wiesman J, Bruce H, et al. Washington state 2019-nCoV case investigation team. First case of 2019 novel coronavirus in the United States. N Engl J Med. 2020;382(10):929-36.

21. Yeo C, Kaushal S, Yeo D. Enteric involvement of coronaviruses: is faecal-oral transmission of SARS-CoV-2 possible?. Lancet Gastroenterol Hepatol. 2020; 5(4):335-7.

22. Wölfel R, Corman VM, Guggemos W, Seilmaier M, Zange S, Müller MA, et al. Virological assessment of hospitalized patients with COVID-2019. Nature. 2020;581 (7809):465-9.

23. Li Z, Yi Y, Luo X, Xiong N, Liu Y, Li S, et al. Development and clinical application of a rapid IgM-lgG combined antibody test for SARS-CoV-2 infection diagnosis. J Med Virol. 2020. https://doi.org/10.1002/jmv.25727.

24. Gandhi M, Yokoe DS, Havlir DV. Asymptomatic transmission, the Achilles' heel of current strategies to control Covid-19. N Engl J Med. 2020;382(22): 2158-60.

25. Arons MM, Hatfield KM, Reddy SC, Kimball A, James A, Jacobs JR, et al. Presymptomatic SARS-CoV-2 infections and transmission in a skilled nursing facility. N Engl J Med. 2020;382(22):2081-90.

26. Zou L, Ruan F, Huang M, Liang L, Huang H, Hong Z, et al. SARS-CoV-2 vira load in upper respiratory specimens of infected patients. N Engl J Med. 2020;382(12):1177-9.

\section{Publisher's Note}

Springer Nature remains neutral with regard to jurisdictional claims in published maps and institutional affiliations.

Ready to submit your research? Choose BMC and benefit from:

- fast, convenient online submission

- thorough peer review by experienced researchers in your field

- rapid publication on acceptance

- support for research data, including large and complex data types

- gold Open Access which fosters wider collaboration and increased citations

- maximum visibility for your research: over $100 \mathrm{M}$ website views per year

At $\mathrm{BMC}$, research is always in progress.

Learn more biomedcentral.com/submissions 